\title{
ANALISIS STRUKTUR DAN KAIDAH KEBAHASAAN TEKS EKSPLANASI SISWA KELAS VIII SMP NEGERI 2 LAWE SIGALA-GALA TAHUN PEMBELAJARAN 2019/2020
}

\begin{abstract}
Liana
Program Studi Pendidikan Bahasa Indonesia, fakultas keguruan dan Ilmu Pendidikan, Universitas Katolik Santo Thomas, Jl. Setia Budi No.479-F Tanjung Sari Medan-Kode Pos No.20132, email lianasiburian302@yahoo.co.id.
\end{abstract}

\begin{abstract}
Abstrak
Penelitian ini bertujuan untuk mendeskripsikan hasil analisis struktur dan kaidah kebahasaan teks eksplanasi yang ditulis Siswa Kelas VIII SMP NEGERI 2 Lawe Sigala-Gala Tahun Pembelajaran 2019/2020. Objek dalam penelitian ini adalah siswa/siswi Kelas VIII SMP NEGERI 2 Lawe Sigala-Gala dengan jumlah 143 orang. Teknik pengumpulan data dalam penelitian ini adalah menggunakan teknik dokumen. Dokumen didapat dari hasil penugasan yang diberikan peneliti kepada siswa yaitu menuliskan teks eksplanasi. Setelah selesai ditulis oleh siswa, maka hasil tulisan dikumpulkan oleh peneliti. Tahap selanjutnya peneliti memulai dengan membaca dan mengklasifikasikan, kemudian data dimasukkan ke dalam tabel analisis teks eksplanasi sesuai dengan struktur dan kaidah kebahasaannya.

Dari 143 data yang telah dianalisis penulis, Sebanyak 131 (91,60\%) siswa sudah mampu menulis struktur teks eksplanasi. Berdasarkan strukturnya antara lain, identifikasi fenomena, penggambaran rangkaian kejadian dan ulasan. Sebanyak 12 (8,39\%) siswa masih belum mampu menulis teks eksplanasi dengan menggunakan semua struktur teks eksplanasi. Sebanyak 2 (1,39\%) siswa tidak mencantumkan pernyataan umum. Sebanyak 10 (6,99\%) siswa tidak mencantumkan kesimpulan. Dari 143 teks eksplanasi yang ditulis siswa, hanya 4 (2,79\%) siswa yang sudah menggunakan keempat ciri kebahasaan teks eksplanasi. Keempat ciri kebahasaan tersebut, yakni konjungsi kausalitas, konjungsi kronologis, kata benda yang merujuk pada jenis fenomena, dan kata teknis atau peristilahan. Sebanyak 139 (97,20\%) siswa tidak menggunakan keempat kaidah kebahasaan teks yang telah ditentukan. $5(3,49 \%)$ siswa tidak mencantumkan konjungsi kausalitas, $134(93,70 \%)$ siswa tidak mencantumkan konjungsi kronologis, 71 (49,65\%) siswa tidak mencantumkan kata benda yang merujuk pada jenis fenomena, dan 61 (42,65\%) siswa tidak mencantumkan kata teknis atau peristilahan.Implikasi penelitian adalah siswa belum mampu menulis teks eksplanasi yang baik dan benar berdasarkan struktur dan kaidah kebahasaannya. Peneliti menyarankan kepada guru mata pelajaran bahasa Indonesia agar materi memproduksi teks perlu diajarkan lebih mendalam lagi supaya siswa mampu menuliskan teks sesuai denga struktur dan kaidah kebahasaan yang baik dan benar. Guru mata pelajaran juga sesering mungkin memberikan latihan kepada siswa untuk menuliskan sebuah teks dan dibahas bersama oleh guru dan siswa sehingga apabila ada kesalahan dalam penulisan teks tersebut dapat diperbaiki dan diberikan penjelasan agar siswa memahami.
\end{abstract}

\section{Kata kunci: Analisis, struktur dan kaidah kebahasaan teks eksplanasi}

\begin{abstract}
This study aims to describe the results of the analysis of the structure and rules of explanatory text written by Grade VIII students of SMP NEGERI 2 Lawe Sigala-Gala for the 2019/2020 Academic Year. The objects in this study were the students of Class VIII SMP NEGERI 2 Lawe Sigala-Gala with a total of 143 people. Data collection techniques in this study are using document techniques.
\end{abstract}


The document was obtained from the results of the assignment given by researchers to students, namely writing explanatory texts. After completion of writing by students, the results of the writing are collected by researchers. The next stage the researcher begins by reading and classifying, then the data is entered into an explanatory text analysis table in accordance with the structure and language rules.

From 143 data analyzed by the writer, $131(91.60 \%)$ students were able to write explanatory text structures. Based on the structure, among others, identification of phenomena, depiction of a series of events and reviews. A total of $12(8.39 \%)$ students were still unable to write explanatory texts using all the explanatory text structures. As many as $2(1.39 \%)$ students did not include a general statement. A total of $10(6.99 \%)$ students did not include a conclusion. Out of 143 explanatory texts written by students, only $4(2.79 \%)$ students have used all four explanatory text linguistic features. The four characteristics of language, namely the conjunctions of causality, chronological conjunctions, nouns that refer to the type of phenomenon, and technical words or terminology. A total of $139(97.20 \%)$ students did not use the four predetermined textual rules. $5(3.49 \%)$ students did not include causality conjunctions, 134 (93.70\%) students did not mention chronological conjunctions, $71(49.65 \%)$ students did not include nouns that refer to types of phenomena, and $61(42.65 \%)$ students do not include technical words or terminology. The implication of the study is that students have not been able to write good and correct explanatory texts based on their language structure and rules. The researcher suggests to Indonesian language teachers that the material to produce texts needs to be taught in more depth so that students are able to write texts according to the structure and rules of language that are good and right. Subject teachers also often give students exercises to write a text and discuss it together by the teacher and students so that if there are errors in writing the text can be corrected and given an explanation so students understand.

Keywords: Analysis, structure and language rules of explanatory tex

\section{PENDAHULUAN}

Menulis merupakan salah satu dari keempat keterampilan berbahasa yang mendasar (berbicara, mendengar, menulis, dan membaca). Secara umum, keterampilanketerampilan berbahasa tersebut dibagi menjadi dua macam, yakni keterampilan produktif dan keterampilan reseptif. Menulis dan berbicara merupakan keterampilan produktif, sedangkan membaca dan mendengar merupakan keterampilan reseptif. Disebut produktif karena keterampilan tersebut digunakan untuk memproduksi bahasa demi penyampaian makna, sedangkan disebut reseptif karena keterampilan tersebut digunakan untuk menangkap dan mencerna makna guna pemahaman terhadap penyampaian dalam bentuk bahasa, baik verbal maupun non-verbal.

Keterampilan berbahasa yang ditekankan di sekolah salah satunya adalah keterampilan menulis. Menulis merupakan suatu keterampilan berbahasa yang digunakan untuk berkomunikasi secara tidak langsung dengan orang lain. Dalam menulis latihan merupakan kunci yang paling utama, seseorang yang ingin menulis tidak cukup dengan mempelajari bahasa dan teori menulis saja karena keterampilan menulis merupakan suatu proses pertumbuhan dengan melalui banyak latihan. Menulis merupakan salah satu keterampilan yang paling efektif untuk menyampaikan gagasan atau ide kreatif. Dalman (2011:3) mengatakan, menulis merupakan suatu kegiatan komunikasi berupa penyampaian pesan (informasi) secara tertulis kepada pihak lain dengan menggunakan bahasa 
tulis sebagai alat atau medianya. Dengan menulis seseorang dapat menuangkan gagasan dalam bentuk bahasa tulis misalnya memberitahukan, meyakinkan, atau menghibur pembaca.

Eksplanasi berasal dari kata bahasa Inggris explanation yang jika diartikan dalam bahasa Indonesia bermakna menjelaskan. Dari istilah tersebut maka muncul definisi bahwa teks eksplanasi adalah suatu teks yang berisikan proses yang berhubungan dengan fenomena alam, sosial, budaya, dan ilmu pengetahuan. Teks eksplanasi adalah teks yang menjelaskan sesuatu proses atau peristiwa asalusul, proses, atau perkembangan suatu fenomena berupa peristiwa alam, sosial, ataupun budaya. Teks eksplanasi merupakan teks yang menjelaskan hubungan logis dari beberapa peristiwa. Suatu kejadian baik kejadian alam maupun kejadian sosial yang terjadi di sekitar kita, selalu memiliki hubungan sebab akibat dan memiliki proses.

\section{KAJIAN KEPUSTAKAAN}

\section{Kajian Teori}

Kajian teori memuat sejumlah teori
yang berkaitan dengan permasalahan
penelitian. Teori-teori tersebut dijadikan
sebagai landasan pemikiran serta titik acuan
bagi penjelasan masalah penelitian. Semua
uraian atau pembahasan terhadap
permasalahan haruslah didukung dengan teori-
teori yang kuat. Mengingat pentingnya hal itu
maka pada bagian ini akan dilengkapi dengan
teori-teori yang sesuai dengan masalah
penelitian.

\section{Menulis}

Menulis merupakan suatu keterampilan berbahasa yang dipergunakan untuk berkomunikasi secara tidak langsung, tidak secara tatap muka dengan orang lain (Tarigan 2013:3). Menurut Semi (2007:14), menulis merupakan suatu proses kreatif memindahkan gagasan kedalam lambanglambang tulisan. Menulis merupakan sebuah proses kreatif menuangkan gagasan dalam bentuk bahasa, misalnya memberitahu, meyakinkan, atau menghibur. Menulis juga dapat dikatakan sebagai kegiatan merangkai huruf menjadi kata atau kalimat untuk disampaikan kepada orang lain, sehingga orang lain dapat memahaminya. Dalam hal ini, dapat terjadinya komunikasi antar penulis dan pembaca dengan baik.

Berdasarkan pendapat di atas dapat ditarik kesimpulan bahwa menulis merupakan suatu kegiatan untuk mengekspresikan diri, menyampaikan gagasan atau pikiran dalam bentuk tulisan dan dapat digunakan sebagai alat komunikasi secara tidak langsung. Untuk dapat menulis dengan baik, diperlukan pemahaman tentang teknik menulis, pemahaman tentang struktur dan kaidah tulisan, penguasaan kosa kata, latihan yang baik serta pengalaman.

Setiap orang yang hendak menulis tentu mempunyai niat atau maksud di dalam hati atau pikiran apa yang hendak dicapainya dengan menulis. Menurut Semi (2007:14-21), tujuan menulis sebagai berikut:

1. Untuk menceritakan sesuatu

Menceritakan sesuatu kepada orang lain mempunyai maksud agar orang lain atau pembaca tahu tentang apa yang dialami yang bersangkutan. Pembaca tahu apa yang diimpikan, dikhayalkan, dan dipikirkan penulis. Dengan begitu, terjadi kegiatan berbagi pengalaman, perasaan, dan pengetahuan.

2. Untuk memberikan petunjuk atau pengarahan

Bila seseorang mengajari orang lain bagaimana mengerjakan sesuatu dengan tahapan yang benar, berarti dia sedang memberi petunjuk atau pengarahan.

3. Untuk menjelaskan sesuatu

Pembaca menjadi paham, pengetahuan bertambah, dan pemahaman pembaca tentang topik yang kamu sampaikan itu menjadi lebih baik.

4. Untuk meyakinkan 
Ada kalanya orang menulis untuk meyakinkan orang lain tentang pendapat atau pandangan mengenai sesuatu. Karena orang sering berbeda pendapat tentang banyak banyak hal. Suatu ketika, seseorang ingin mengajak orang lain untuk percaya dengan pandangannya karena dia merasa apa yang dipikirkannya dan dilakukannya merupakan sesuatu yang benar.

5. Untuk merangkum

Ada kalanya orang menulis untuk merangkumkan sesuatu. Dengan menuliskan rangkuman, berarti mereka akan sangat tertolong dan sangat mudah dalam mempelajari isi buku yang panjang dan tebal.

\section{Pengertian Teks Eksplanasi}

\begin{abstract}
Dalam Kamus Besar Bahasa Indonesiaditulis bahwa,eksplanasi berarti penjelasan atau paparan. Namun dalam kaitannya dengan genre teks, eksplanasi merupakan teks yang menjelaskan sesuatu proses atau peristiwa alam,sosial,ataupun budaya. Waluyo (2013:64), teks eksplanasi adalah teks yang bertujuan menjelaskan proses-proses atau tahap-tahap proses yang menjadi bagian dari sebuah informasi baik yang sifatnya alami (natural) maupun yang terjadi dengan campur tangan manusia. Wahono (2013:111), teks eksplanasi pada hakikatnya merupakan teks yang menjelaskan proses terjadinya sesuatu secara alamiah. Teks eksplanasi merupakan teks yang menjelaskan tentang proes mengapa dan bagaimana kejadian baik kejadian alam atau sosial yang terjadi disekitar kita yang selalu memiliki hubungan sebab akibat dalam setiap prosesnya.

Berdasarkan pendapat diatas dapat ditarik kesimpulan bahwa teks eksplanasi adalah teks yang menjelaskan atau memaparkan tentang suatu proses mengapa dan bagaimana sebuah peristiwa atau kejadiankejadian alam, sosial, ilmu pengetahuan, budaya dapat terjadi.
\end{abstract}

\section{Struktur Teks Eksplanasi}

Teks eksplanasi memiliki struktur yang terdiri dari pernyataan umum, dilanjutkan dengan urutan sebab akibat dan diakhiri dengan interpretasi. Untuk leboh memahami lagi mengenai struktur tersebut silahkan simak uraian berikut ini.

1. Pernyataan Umum, Berisi tentang penjelasan umum tentang fenomena yang akan dibahas, bisa berupa pengenalan fenomena tersebut atau penjelasannya. Penjelasan umum yang dituliskan dalam teks ini berupa gambaran secara umum tentang apa, mengapa, dan bagaimana proses peristiwa alam tersebut bisa terjadi.

2. Deretan Penjelas, Berisi tentang penjelasan proses mengapa fenomena tersebut bisa terjadi atau tercipta dan bisa terdiri lebih dari satu paragraf. Deretan penjelas mendeskripsikan dan merincikan penyebab dan akibat dari sebuah bencana alam yang terjadi.

3. Interpretasi (Opsional), Teks penutup yang bersifat pilihan; bukan keharusan. Teks penutup yang dimaksud adalah, teks yang merupakan intisari atau kesimpulan dari pernyataan umum dan deretan penjelas. Opsionalnya dapat berupa tanggapan maupun mengambil kesimpulan atas pernyataan yang ada dalam teks tersebut (Mahsun, 2013)

Menurut Kosasih (2017:138), teks eksplanasi dibentuk dengan struktur sebagai berikut:

1. Identifikasi fenomena, mengidentifikasi sesuatu yang akan diterangkan. Hal itu bisa terkait dengan fenomena alam, sosial, budaya, dan fenomenafenomena lainnya.

2. Penggambaran rangkaian kejadian, sebagai perincian atas kejadian yang relevan 


\section{Skematik Eksplanasi}

dengan identifikasi fenomena.Bagian ini dapat disusun dengan pola kausalitas ataupun kronoligis.

3. Ulasan, berupa komentar, penilaian atau tentang konsekuensi atas kejadian yang dipaparkan sebelumnya.

1. General Statement, Berisi satu statemen umum tentang suatu topik, yang akan dijelaskan proses keberadaannya keberadaannya, proses terjadinya terjadinya, proses terbentuknya, dsb. Harus bersifat ringkas, menarik, dan jelas, yang mampu membangkitkan minat pembaca untuk membaca detailnya.

2. Sequence of explanations, Berisikan tentang detail penjelasan proses keberadaan, proses terjadinya. Sangat relatif untuk menjawab pertanyaan how, yang jawabannya berupa statemen atau declarative sentence. Penggunaan sequence markers sangat dimungkinkan mengingat proses perlu dijelaskan bertahap, pertama, kedua, ketiga, dsb. atau pertama, berikutnya, terakhir.

3. Closing, Berisikan kesimpulan atau statemen tentang topik/proses yang dijelaskan.

Menulis teks eksplanasi merupakan sebuah komponen yang dibelajarakan dalam suatu kegiatan belajara mengajar. Kegiatan menulis teks ini merupakan kegiatan dari hasil pengamatan siswa mengenai teks tersebut. Hasil akhir dari sebuah pembelajaran adalah menulis hasil observasi siswa mengenai teks ini, baik isi, struktur, maupun kebahasaan yang terdapat dalam teks eksplanasi.

Kaidah Kebahasaan Teks Eksplanasi
Menurut Kosasih (2017:144), kaidah kebahasaan teks eksplanasi sebagai berikut:

1. Menggunakan konjungsi kausalitas (sebabakibat), antara lain, sebab, karena, oleh sebab itu, oleh karena itu, sehingga. Konjungsi sebab-akibat menghubungkan satuan kebahasaan untuk menyatakan hubungan sebab-akibat. Suatu proses fenomena alam dijelaskan dengan mengurutkan kejadian-kejadian. Kejadian satu umumnya mengakibatkan kejadian yang lain. Oleh karena itu, konjungsi sebabakibat digunakan untuk menulis teks eksplanasi.

2. Menggunakan konjungsi kronologis (hubungan waktu), seperti kemudian, lalu, setelahitu, padaakhirnya. Konjungsi waktu digunakan dalam teks eksplanasi karena teks tersebut berisi proses terjadinya sesuatu. Proses terjadinya sesuatu umumnya dijelaskan dengan urutan waktu. Oleh karena itu, konjungsi waktu digunakan dalam teks eksplanasi.

3. Menggunakan kata benda yang merujuk pada jenis fenomena, bukannya pada kata ganti penceritanya.

4. Di dalam teks itu pun sering dijumpai kata teknis atau peristilahan, sesuai dengan topik yang dibahasnya.

\section{Langkah-langkah Menulis Teks Eksplanasi}

Teks eksplanasi adalah teks yang menjelaskan proses terjadinya peristiwa dengan sejelas-jelasnya. Dalam penyusunannya, teks eksplanasi umumnya berpola kronologis ataupun kausalitas. Menurut Kosasih (2017:150), langkah-langkah menulis teks eksplanasi sebagai berikut:

1. Menentukan topik atau suatu kejadian yang menarik, dikuasai, dan aktual.

2. Menyusun kerangka teks, yakni dengan mengembangkan topik utama ke dalam rincian-rincian topik yang lebih spesifik. Topik-topik itu dapat disusun dengan urutan kronologis atau kausalitas. 
3. Mengumpulkan bahan, berupa fakta atau pendapat para ahli terkait dengan kejadian yang dituliskan dari berbagai sumber, misalnya melalui observasi lapangan ataupun dengan studi literatur.

4. Mengembangkan kerangka yang telah disusun menjadi teks eksplanasi yang lengkap dan utuh dengan memperhatikan struktur bakunya: identifikasi fenomena/kejadian, proses kejadian, dan ulasan.

\section{METODOLOGI PENELITIAN}

\section{Pendekatan dan Metode Penelitian}

Metode penelitian merupakan rangkaian cara atau kegiatan pelaksanaan penelitian yang didasari oleh asumsi dasar dan pertanyaan terhadap suatu masalah yang dihadapi. Metode penelitian memiliki sebuah rancangan untuk mencapai tujuan penelitian. Tujuan yang dimaksud untuk mengarahkan peneliti merancang sebuah kegiatan penelitian agar dapat memberikan jawaban yang sahih terhadap pertanyaan-pertanyaan yang diajukan peneliti dalam rumusan masalah. Arikunto (2013:203) menyatakan bahwa, metode penelitian adalah cara yang digunakan oleh peneliti dalam mengumpulkan data penelitiannya.

Metode yang digunakan dalam penelitian ini adalah metode deskriptif kualitatif. Penelitian dengan metode deskriptif kualitatif bukan berupa angka melainkan dengan kata-kata. Deskriptif kualitatif adalah penelitian yang dimaksudkan untuk menyelidiki keadaan, kondisi atau lain-lain yang sudah disebutkan, yang hasilnya dipaparkan dalam bentuk laporan penelitian. Menurut Sugiyono (2010:9), metode penelitian kualitatif adalah metode penelitian yang berlandaskan pada filsafat postpositivisme, digunakan untuk meneliti pada kondisi objek yang alamiah, dimana peneliti adalah sebagai instrumen kunci, teknik pengumpulan data dilakukan secara triangulasi (gabungan), analisis data bersifat induktif /kualitatif, dan hasil penelitian kualitatif lebih menekankan makna daripada generalisasi.

Penelitian deskriptif kualitatif ini dilakukan dengan menganalisis struktrur dan kaidah kebahasaan teks eksplanasi siswa Kelas VIII SMP Negeri 2 Lawe Sigala-Gala Tahun Pembelajaran 2019/2020.

Jenis dan Sumber Data

Sumber data dalam penelitian adalah subjek dari mana data dapat diperoleh. Sumber dalam penelitian ini adalah teks eksplanasi yang ditulis siswa Kelas VIII SMP Negeri 2 Lawe Sigala-Gala Tahun Pembelajaran 2019/2020.

\section{Subjek Penelitian}

Subjek penelitian adalah sesuatu yang diteliti baik orang, benda ataupun lembaga (organisasi) yang akan dikenai simpulan dari hasil penelitian yang dilakukan. Sugiyono (2010:80) mengatakan, populasi adalah wilayah generalisasi yang terdiri atas objek atau subjek yang mempunyai kualitas dan karakteristik tertentu yang ditetapkan oleh peneliti untuk dipelajari dan kemudian ditarik kesimpulannya.Yang menjadi subjek dalam penelitian ini adalah seluruh siswa Kelas VIII SMP Negeri 2 Lawe Sigala-Gala Tahun Pembelajaran 2019/2020 dengan jumlah siswa 143 orang. Arikunto (2013:174) mengatakan, sampel adalah sebagian atau wakil populasi yang diteliti. Dalam penelitian ini peneliti menggunakan sampel bertujuan (purposive sampling). Tujuannya agar peneliti dalam mengmbil subjek bukan didasarkan atas strata, random atau daerah, tetapi didasarkan atas adanya tujuan peneliti.

Sampling purposive adalah teknik teknik penentuan sampel dengan pertimbangan tertentu Sugiyono (2010:85). Pertimbangan tertentu ini misalnya orang yang dianggap tahu tentang apa yang kita harapkan sehingga akan memudahkan peneliti menjelajahi objek/situasi yang diteliti.

Jadi, penentuan sampel dalam penelitian kualitatif dilakukan saat peneliti 
mulai memasuki lapangan dan selama penelitian berlangsung. Menurut Sugiyono (2010:221) sampel sebagai sumber data atau sebagai informan sebaiknya yang memenuhi kriteria sebagai berikut:

1. Mereka yang menguasai atau memahami sesuatu melalui proses enkulturasi, sehingga sesuatu itu bukan hanya sekedar diketahui, tetapi juga dihayati.

2. Mereka yang tergolong masih sedang berkecimpung atau terlibat pada kegiatan yang tengah diteliti.

3. Mereka yang mempunyai waktu yang memadai untuk dimintai informasi.

\section{Tahapan Penelitian}

Tahapan yang dilakukan dalam penelitian ini, sebagai berikut :

1. Menentukan masalah penelitian, dalam hal ini peneliti mengadakan studi pendahuluan

\begin{tabular}{|l|l|l|l|}
\hline No. & $\begin{array}{c}\text { Nama } \\
\text { siswa }\end{array}$ & Struktur teks eksplanasi & $\begin{array}{c}\text { Peristiw } \\
\text { a }\end{array}$ \\
\hline \multirow{2}{*}{} & & Identifikasi fenomena & \\
\cline { 3 - 4 } & & Rangkaian kejadian & \\
\cline { 3 - 4 } & & Ulasan & \\
\hline
\end{tabular}

atau observasi di lapangan.

2. Pengumpulan data, pada tahap ini peneliti mulai menentukan sumber data, yaitu bukubuku atau referensi yang berkaitan dengan permasalahan sebagai pendukung

\begin{tabular}{|c|l|l|l|}
\hline No. & $\begin{array}{c}\text { Nama } \\
\text { Siswa }\end{array}$ & \multicolumn{1}{|c|}{$\begin{array}{c}\text { Ciri kebahasaan teks } \\
\text { eksplanasi }\end{array}$} & Kalimat \\
\hline \multirow{2}{*}{} & $\begin{array}{l}\text { Menggunakan konjungsi } \\
\text { kausalitas (sebab, karena, } \\
\text { sehingga). }\end{array}$ & \\
\cline { 3 - 4 } & $\begin{array}{l}\text { Menggunakan konjungsi } \\
\text { kronologis (kemudian, lalu). }\end{array}$ & \\
\cline { 3 - 5 } & $\begin{array}{l}\text { Menggunakan kata benda } \\
\text { yang merujuk pada jenis } \\
\text { fenomena. }\end{array}$ & \\
& $\begin{array}{l}\text { Menggunakan kata teknis } \\
\text { atau peristilahan. }\end{array}$ & \\
\hline
\end{tabular}

penelitian. Pada tahap ini diakhiri dengan

ISSN 15421-71667

Volume 2 Nomor 2 Desember 2019 pengumpulan data dengan menggunakan metode observasi, baca catat, dan dokumentasi.

3. Analisis dan penyajian data, yaitu menganalisis data yang telah diperoleh, dan akhir ditarik suatu kesimpulan.

\subsection{Teknik dan Pengumpulan Data}

Tenik pengumpulan data merupakan langkah yang paling strategis dalam penelitian, karena tujuan utama dari penelitian adalah mendapatkan data. Tanpa mengetahui teknik pengumpulan data, maka peneliti tidak akan mendapatkan data yang memenuhi standar data yang ditetapkan. Teknik pengumpulan data dalam penelitian ini menggunakan teknik dokumen. Sugiyono (2010:240) mengatakan dokumen bisa berbentuk tulisan, gambar, atau karya-karya monumental dari seseorang. Dokumen yang berbentuk tulisan misalnya catatan harian, sejarah kehidupan, ceritera, biografi, peraturan, kebijakan.Dokumentasi yang peneliti kumpulkan dalam penelitian ini adalah foto pada pelaksanaan pembelajaran dan hasil pembelajaran menulis teks eksplanasi siswa Kelas VIII SMP Negeri 2 Lawe SigalaGala Tahun Pembelajaran 2019/2020. Pengumpulan data dalam penelitian ini didapat dari hasil penugasan yang diberikan peneliti kepada siswa, tujuannya untuk menganalisis struktur dan kaidah kebahasaan teks eksplanasi yang dibuat oleh siswa.

Setelah mengumpulkan hasil tulisan siswa, peneliti memulai dengan membaca teks eksplanasi yang dituliskan siswa dengan teliti dan cermat, selanjutnya data yang telah terkumpul dikaji oleh peneliti. Teknik catat adalah mencatat sumber data kedalam bentuk tulisan. Setelah peneliti membaca, data dicatat selanjutnya dikategorikan dalam bentuk tabel.

Tabel Analisis Struktur Teks Eksplanasi

Wirasatya, dkk, 2014:3

Tabel 3.4

Tabel Analisis Kaidah Kebahasaan Teks Eksplanasi 
Wirasatya, dkk, 2014:5

\section{Instrumen Penelitian}

Instrumen adalah alat pada waktu penelitian menggunakan sesuatu metode. Sugiyono (2010:102) menyatakan, instrumen penelitian adalah suatu alat yang digunakan mengukur fenomena alam maupun sosial yang diamati. Instrumen penelitian adalah alat atau fasilitas yang digunakan oleh peneliti dalam mengumpulkan data agar pekerjaannya lebih mudah dan hasilnya lebih baik, dalam arti lebih cermat, lengkap, dan sistematis sehingga lebih mudah diolah. Instrumen penelitian merupakan alat yang digunakan oleh peneliti untuk mempermudah pekerjaan dalam mengumpulkan data dalam penelitian, instrumen penelitian yang digunakan dalam penelitian ini adalah data teks eksplanasi yang dituliskan oleh siswa.

Dalam penelitian kualitatif, yang menjadi instrumen atau alat penelitian adalah peneliti itu sendiri. Oleh karena itu peneliti sebagai instrumen juga harus "divalidasi" seberapa jauh peneliti kualitatif siap melakukan penelitian yang selanjutnya terjun ke lapangan.Peneliti kualitatif sebagai human instrument, berfungsi menetapkan fokus penelitian, memilih informan sebagai sumber data, melakukan pengumpulan data, menilai kualitas data, analisis data, menafsirkan data dan membuat kesimpulan atas semuanya.

\section{Teknik Pengolahan dan Analisis Data}

Analisis data adalah proses mencari dan menyusun secara sistematis data yang diperoleh dari hasil wawancara, catatan lapangan, dan dokumentasi, dengan cara mengorganisasikan data ke dalam kategori, menjabarkan ke dalam unit-unit, melakukan sintesa, menyusun ke dalam pola, memilih mana yang penting dan yang akan dipelajari, dan membuat kesimpulan sehingga mudah dipahami oleh diri sendiri maupun orang lain. Nasution (1988) dalam Sugiyono menyatakan, analisis telah mulai sejak merumuskan dan menjelaskan masalah, sebelum terjun kelapangan, dan berlangsung terus sampai penulisan hasil penelitian. Analisis data penelitian kualitatif dilakukan sejak sebelum memasuki lapangan, selama di lapangan, dan setelah selesai di lapangan. Namun dalam penelitian kualitatif, analisis data lebih difokuskan selama proses di lapangan bersamaan dengan pengumpulan data.

Teknik pengolahan data dalam penelitian ini adalah, sebagai berikut:

1. Mengumpulkan semua data yang diperoleh berupa teks eksplanasi siswa Kelas VIII SMP Negeri 2 Lawe Sigala-Gala Tahun Pembelajaran 2019/2020.

2. Membaca teks eksplanasi yang ditulis oleh siswa Kelas VIII SMP Negeri 2 Lawe Sigala-Gala Tahun Pembelajaran 2019/2020.

3. Memilah teks ekplanasi siswa yang sesuai dengan struktur teks eksplanasi dan kaidah kebahasaannya.

4. Mencermati penulisan teks eksplanasi yang ditulis oleh siswa.

5. Memasukkan teks eksplanasi yang ditulis oleh siswa berdasarkan struktur dan kaidah kebahasaannya ke dalam bentuk tabel.

6. Memaparkan teks eksplanasi yang ditulis oleh siswa berdasarkan struktrur dan kaidah kebahasaan yang terdapat pada tabel.

Langkah-langkah analisis data yang dilakukan dalam penelitian ini adalah :

1. Reduksi data Mereduksi data berarti merangkum, memilih hal-hal yang 
pokok, memfokuskan pada hal-hal yang penting, dengan demikian data yang telah direduksi akan memberikan gambaran yang lebih jelas dan mempermudah peneliti untuk melakukan pengumpulan data Sugiyono (2010:247). Reduksi data yang dilakukan dalam penelitian ini adalah peneliti mengumpulkan data dengan menggolongkan berdasarkan instrumen analisis struktur dan kaidah kebahasaan teks eksplanasi.

2. Penyajian data

Penyajian data dalam penelitian kualitatif dapat dilakukan dalam bentuk uraian singkat, bagan, hubungan antar kategori, dan sejenisnya. Penyajian data yang sering digunakan adalah dengan teks yang bersifat naratif Sugiyono (2010:249). Penyajian data dalam penelitian ini adalah dalam bentuk uraian atau teks yang bersifat deskripsi. Penyajian data dilakukan dengan menyajikan uraian singkat tiap komponen yang terdapat dalam tabel analisis struktur dan kaidah kebahasaan teks eksplanasi.

3. Penarikan Kesimpulan.

Kesimpulan dalam penelitian kualitatif adalah merupakan temuan baru yang sebelumnya belum pernah ada. Temuan dapat berupa deskripsi atau gambaran suatu objek yang sebelumnya masih remang-remang atau gelap sehingga setelah diteliti menjadi jelas, dapat berupa hubungan kausal atau interaktif, hipotesis atau teori Sugiyono (2010:252). Simpulan dalam penelitian ini berupa deskripsi mengenai Analisis Struktur dan Kaidah
Kebahasaan Teks Eksplanasi siswa Kelas VIII SMP Negeri 2 Lawe Sigala-Gala Tahun Pembelajaran 2019/2020.

Berdasarkan hasil penelitian dan pembahasan yang telah dilakukan oleh penulis mengenai "Analisis Struktur dan Kaidah Kebahasaan Teks Eksplanasi siswa Kelas VIII SMP Negeri 2 Lawe Sigala-Gala Tahun Pembelajaran 2019/2020" maka didapat simpulan sebagai berikut:

1. Dari 143 data yang telah dianalisis penulis, Sebanyak $131 \quad(91,60 \%)$ siswa sudah mampu menulis struktur teks eksplanasi. Berdasarkan strukturnya antara lain, identifikasi fenomena, penggambaran rangkaian kejadian dan ulasan. Sebanyak 12 $(8,39 \%)$ siswa masih belum mampu menulis teks eksplanasi dengan menggunakan semua struktur teks eksplanasi. Sebanyak 2 (1,39\%) siswa tidak mencantumkan pernyataan umum. Sebanyak 10 $(6,99 \%)$ siswa tidak mencantumkan kesimpulan.

2. Dari 143 teks eksplanasi yang ditulis siswa, hanya $4(2,79 \%)$ siswa yang sudah menggunakan keempat kaidah kebahasaan teks eksplanasi. Keempat kaidah kebahasaan tersebut, yakni konjungsi kausalitas, konjungsi kronologis, kata benda yang merujuk pada jenis fenomena, dan kata teknis atau peristilahan. Sebanyak 139 $(97,20 \%)$ siswa tidak menggunakan keempat kaidah kebahasaan teks yang telah ditentukan. 5 (3,49\%) siswa tidak mencantumkan konjungsi kausalitas, 134 (93,70\%) siswa tidak mencantumkan konjungsi kronologis, $71(49,65 \%)$ siswa tidak mencantumkan kata benda yang merujuk pada jenis fenomena, dan 61 $(42,65 \%)$ siswa tidak mencantumkan kata teknis atau peristilahan. 


\section{DAFTAR KEPUSTAKAAN}

Arikunto, Suharsimi. 2013. Prosedur Penelitian Suatu Pendekatan Praktik. Jakarta : Rineka Cipta.

Dalman, H.2015. Keterampilan Menulis. Bandar Lampung: Raja Grafindo Persada.

Kokasih. 2014. Jenis-jenis Teks. Bandung: Yrama Widya.

Kosasih, E. 2017. Bahasa Indonesia. Jakarta : Pusat Kurikulum dan Perbukuan, Kalitbag, Kemendikbud.

Semi, Atar. 2007. Dasar-dasar Keterampilan Menulis. Bandung. Angkasa Bandung.

Sugiyono. 2010. Metode Penelitian Kuantitatif Kualitatif dan $R \& D$. Bandung: Alfabeta.

Tarigan, Henry Guntur. 2013. Menulis Sebagai Suatu Keterampilan Berbahasa. Bandung: Angkasa Bandung.

Wahono, dkk. 2013. Mahir Berbahasa Indonesia. Jakarta. Erlangga.

Waluyo, Budi. 2013. Bahasa dan Sastra Indonesia. Solo. Platinum. 